\title{
Studies on Microbial Contaminants Associated with Arecanut Leaf Sheath Plates
}

\author{
R.M. Revathi (i), Nagarajappa Adivappar* (D), Suresh Patil, \\ H.P. Sudeep and H.C. Swathi
}

Arecanut Research Centre, University of Agricultural and Horticultural Sciences, Shivamogga - 577204, India.

\begin{abstract}
Arecanut is being grown in an area of 2.71 lakh ha in Karnataka and contributes 65 per cent area to the country. Arecanut sheds the leaf sheath and they are widely used for consumption and packing of food in various occasions. The survey was conducted to know the microbial contaminants associated with leaf sheath plates and during the survey visited to 30 plates manufacturing units situated in Shivamogga and Davanagere districts in Karnataka. Randomly collected areca plates were used for laboratory study to know the contaminants. From these, fungal and bacterial contaminants were isolated and identified by cultural, morphological and biochemical studies. The result revealed that Rhizopus stolonifer, Penicillium citrinum, Aspergillus niger, Aspergillus flavus and Trichoderma harzianum and prevalence of Pseudomonas sp. $\left(32 \times 10^{-6} \mathrm{cfu} / \mathrm{ml}\right)$, Bacillus sp. $\left(19 \times 10^{-6} \mathrm{cfu} / \mathrm{ml}\right)$, Micrococcus $\mathrm{sp} .\left(12 \times 10^{-6} \mathrm{cfu} / \mathrm{ml}\right)$ and $E$. coli $\left(4 \times 10^{-6} \mathrm{cfu} / \mathrm{ml}\right)$ were observed in contaminated plates under laboratory studies. The study concluded that the prevalence of fungi and bacteria may cause deleterious effects on human health is a chance factor. In future, it is required to concentrate on the sterilizing process which may prevent the health hazardous on human beings.
\end{abstract}

Keywords: Arecanut sheath plate, contaminants, Human health

*Correspondence: nagarajappaadivappar@uahs.edu.in

(Received: April 20, 2021; accepted: June 24, 2021)

Citation: Revathi RM, Adivappar N, Patil S, Sudeep HP, Swathi HC. Studies on Microbial Contaminants Associated with Arecanut Leaf Sheath Plates. J Pure App/ Microbiol. 2021;15(3):1393-1397. doi: 10.22207/JPAM.15.3.31

(C) The Author(s) 2021. Open Access. This article is distributed under the terms of the Creative Commons Attribution 4.0 International License which permits unrestricted use, sharing, distribution, and reproduction in any medium, provided you give appropriate credit to the original author(s) and the source, provide a link to the Creative Commons license, and indicate if changes were made. 


\section{INTRODUCTION}

Arecanut palm (Areca catechu L.) leaf sheath sheds naturally which have been used as an ecofriendly food serving and filling material for centuries (Kalita et al) ${ }^{1}$. Nowadays with modern technology, this natural and rigid material is compressed into different shapes and used to serve and pack food. The micro enterprise units manufacturing plates from areca leaf sheath are concentrated in major arecanut growing districts in Karnataka viz., Shivamogga, Davanagere, Chikkamagalur, Chitradurga, Dakshina Kannada, Udupi and Uttar Kannada. Leaf Sheath goes waste if not properly utilized for making usable commodities which may helps to small and marginal entrepreneurs for better prize (Adivappar et $\mathrm{al})^{2}$. The prevalence of contaminants in leaf materials may cause food spoilage and also results in reduction in quality (Omidbeygi et al) ${ }^{3}$. Some of the fungal species are toxic and may produce mycotoxins in food packing and serving material cause a hazard to human health.

\section{MATERIAL AND METHODS}

In present investigation, contaminated plates were randomly collected from 30 plate making units from different places of Shivamogga and Davanagere districts of Karnataka. The main objective of investigation is to find out the contaminants which are present in the plates under in vitro. Contaminated leaf plate samples were chopped into small pieces and it was aseptically surface sterilized by immersing in sodium hypochlorite $(1 \%)$ for 30 seconds then poured in a conical flask containing sterile distilled water.

\section{Isolation of bacterial contaminants}

The procedure was followed as per serial dilution technique and pour plate procedure were followed to identify the bacterial colonies then plates were kept at $27^{\circ} \mathrm{C}$ for 24 to $36 \mathrm{hrs}$. After incubation, the colonies on nutrient agar plate were counted from different dilutions such as $10^{-6}, 10^{-7}$. Bacterial morphology was studied microscopically by Gram staining technique and recognized by following biochemical tests.

\section{Biochemical characterization of bacteria}

Biochemical tests viz., Gram reaction, $\mathrm{KOH}$ solubility, catalase test, starch hydrolysis, gelatine liquefaction, H2S production, protein digestion, ammonia production, methyl red tests were carried out as per the methods described in laboratory guide for Identification of Bacteria (Schaad) $)^{4}$.

\section{Isolation of fungal contaminanats}

The samples were taken into laboratory for surface sterilization then made into small pieces and kept for incubation at $27^{\circ} \mathrm{C}$ for three days. Fungi which are present in the sample were cultured on PDA plates and observed under microscope.

Cultural and morphological characterization of fungi

The randomly collected areca leaf sheath plates were used for microbial studies. A $5 \mathrm{~mm}$ diameter disc of sterile cork borer was used to cut the vigorously growing edge of a fresh culture then placed on Petri plates containing medium (PDA). The set of cultured Petri dishes were incubated at $27^{\circ} \mathrm{C}$ then fungal growth was examined. For morphological studies isolated fungal culture slides were prepared then observed under microscope.

\section{RESULTS}

Survey was conducted to know the microbial contaminants associated with leaf sheath plates and during the survey visited
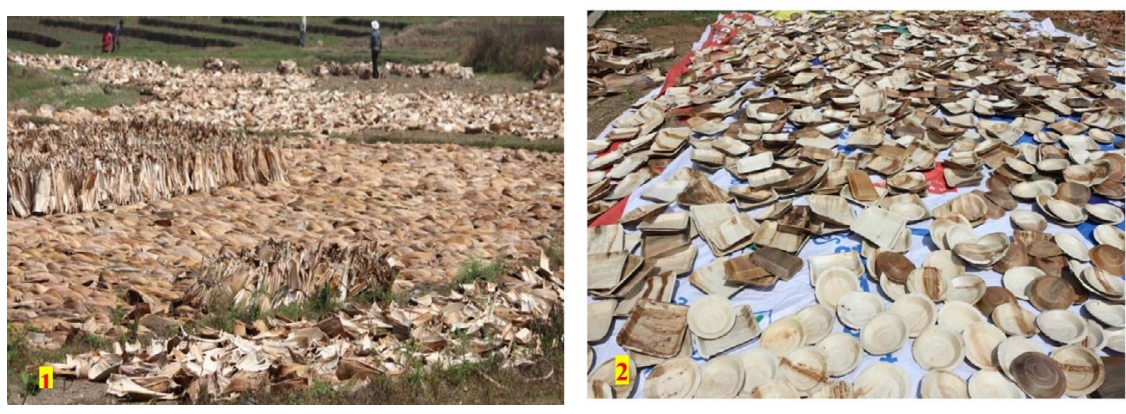

Fig. 1 \& 2. Manufacturing units drying the leaf sheath and plates in open condition 
to 30 plates manufacturing units situated in Shivamogga and Davanagere districts in Karnataka (Fig. 1, 2). In this study, the contaminated areca leaf plate (Fig. 3) was used for microbial analysis under laboratory condition. Prevalence of fungal contaminats Rhizopus stolonifer, Penicillium

Table 1. Prevalence of fungal contaminants in areca leaf sheath plate

\begin{tabular}{|c|c|c|c|}
\hline SI.No. & Fungal contaminants & Culture & References \\
\hline 1 & Rhizopus stolonifer & $\begin{array}{l}\text { Dense cottony growth first white then become grey } \\
\text { or yellowish brown with spore production }\end{array}$ & Dolatabadi et al $^{9}$ \\
\hline 2 & Penicillium citrinum & Shades of green, sometimes white & Visagie et al $^{10}$ \\
\hline 3 & Aspergillus niger & Black cottony growth & Gams et. $a^{11}$ \\
\hline 4 & Aspergillus flavus & Granular growth, bright to dark yellow-green & Hedayati et al ${ }^{12}$ \\
\hline 5 & Trichoderma harzianum & $\begin{array}{l}\text { Initially white and downy, later it developing deep } \\
\text { green compact mass, look like concentric ring-like } \\
\text { zones }\end{array}$ & Sandoval-denis et $\mathrm{al}^{13}$ \\
\hline
\end{tabular}

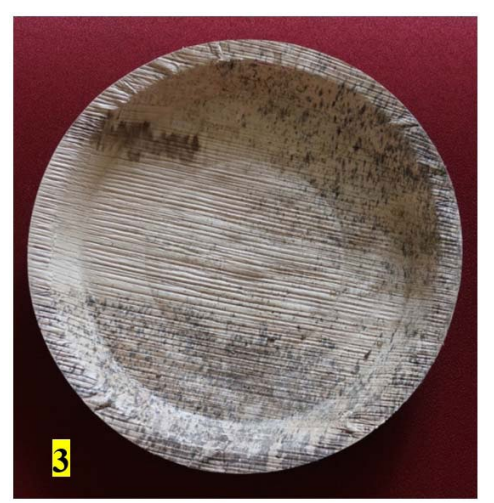

citrinum, Aspergillus niger, A. flavus, Trichoderma harzianum were grown in the culture plate (Table 1), among the fungal contaminants most of the samples were contaminated with Aspergillus niger (Fig. 4,5) and A. flavus (Fig. 6,7). Biochemical characters to determine the colonies of bacteria among that highest prevalence were observed in Pseudomonas sp. $\left(32 \times 10^{-6} \mathrm{cfu} / \mathrm{ml}\right)$ followed by Bacillus sp. $\left(19 \times 10^{-6} \mathrm{cfu} / \mathrm{ml}\right)$, Micrococcus sp. $\left(12 \times 10^{-6} \mathrm{cfu} / \mathrm{ml}\right)$ and $E$. coli $\left(4 \times 10^{-6} \mathrm{cfu} / \mathrm{ml}\right)$ and following were given in Table 2 .

Fig. 3. Contaminated sample
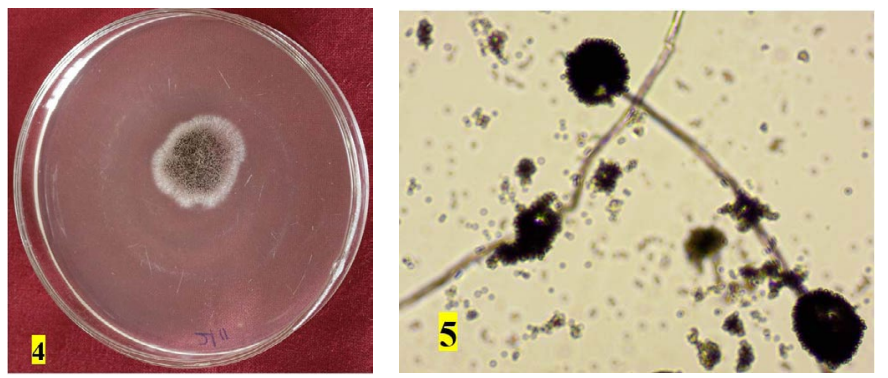

Fig. 4 \& 5. Cultural and morphological characteristics of Aspergillus niger
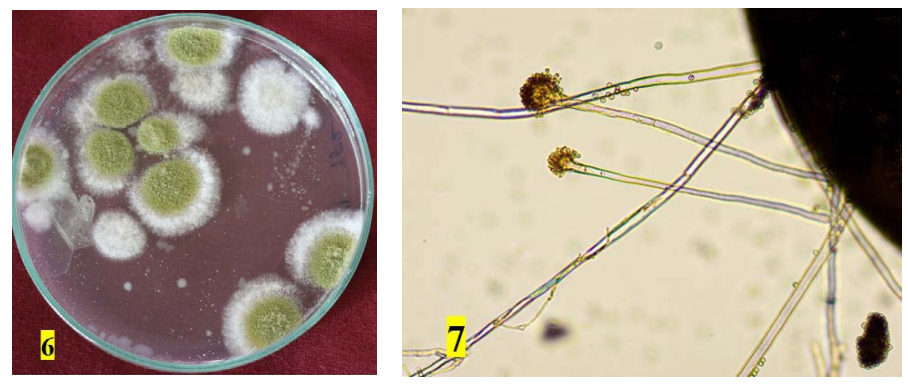

Fig. 6 \& 7. Cultural and morphological characteristics of $A$. flavus 
Table 2. Prevalence of bacterial contaminants in areca leaf sheath plate

\begin{tabular}{llll}
\hline SL.No. & $\begin{array}{l}\text { Prevalent } \\
\text { contaminants }\end{array}$ & $\begin{array}{l}\text { Bacterial count } \\
\left(10^{-6} \mathrm{cfu} / \mathrm{ml}\right)\end{array}$ & Colony characters \\
\hline 1. & Bacillus sp. & 19 & $\begin{array}{l}\text { Colonies are rough, opaque, fuzzy white or slightly yellow with } \\
\text { irregular edges and circular in shape. Gram positive } \\
\text { Colonies are circular, yellow, convex and smooth. Gram positive } \\
\text { Colonies are large, opaque, flat colonies with irregular margins } \\
\text { and distinctively fruity odour. Gram negative } \\
\text { Off-white or beige in color with a shiny texture slightly raised } \\
\text { 3. }\end{array} \quad \begin{array}{l}\text { Micrococcus sp. } \\
\text { colonies. Gram negative }\end{array}$ \\
\hline
\end{tabular}

\section{DISCUSSION}

Areca leaf plates were used for microbial analysis under laboratory condition. Biochemical characters determine the colonies of bacteria among that highest prevalence was observed in Pseudomonas sp. $\left(32 \times 10^{-6} \mathrm{cfu} / \mathrm{ml}\right)$ followed by Bacillus sp. $\left(19 \times 10^{-6} \mathrm{cfu} / \mathrm{ml}\right)$, Micrococcus sp. $\left(12 \times 10^{-6} \mathrm{cfu} / \mathrm{ml}\right)$ and E. coli $\left(4 \times 10^{-6} \mathrm{cfu} / \mathrm{ml}\right)$. Similar studies were carried out by Janaki et al ${ }^{5}$. reported that areca leaf sheath plates were easily get contaminated by bacteria when compared to other microbes. In case of fungal contaminats prevalence of Rhizopus stolonifer, Penicillium citrinum, Aspergillus niger, Aspergillus flavus, Trichoderma harzianum were grown in the culture plate, Matan et al ${ }^{6}$ also identified mold growth on areca leaf sheath such as Mucor dimorphosporus, Penicillium sp., Aspergillus niger and Rhizopus sp. etc. The contaminants are uaually attached on the surface of plates after the process of manufacture in unit under unhygienic condition was resulted the molds could be observed on plates within a week (Nitimongkonchi) ${ }^{7}$. Lyratzopoulos et al ${ }^{8}$, reported that several species of Penicillium are common contaminants on diverse substrates and are called as potential mycotoxin producers. Identification of Penicillium contamination in food is more important where human pathogenic species are rare, however in favorable condition infections leading to mycotic keratitis, otomycosis and endocarditis. So there is a need to concentrate on sterilization techniques like UV irradiation treatment to avoid any serious health issue on human beings by using different by products of arecanut leaf sheath viz., plates, cups and food packing materials.

\section{ACKNOWLEDGEMENT}

Authors are grateful to Director of Research, University of Agricultural and Horticultural Sciences, Shivamogga, India for providing the necessary facilities.

\section{CONFLICT OF INTEREST}

The authors declare that there is no conflict of interest.

\section{AUTHOR'S CONTRIBUTION}

All authors listed have made substantial, direct and intellectual contribution to the work, and approved it for publication.

\section{FUNDING}

None

\section{DATA AVAILABILITY}

All datasets generated or analyzed during this study are included in the manuscript.

\section{ETHICS STATEMENT}

This article does not contain any studies with human participants or animals performed by any of the authors.

\section{REFERENCES}

1. Kalita P, Dixit US, Mahanta P, Saha UK. A novel energy efficient machine for plate manufacturing from areca palm leaf sheath. J. Sci. Indu. Res. 2008; 67:807-811.

2. Adivappar N, Hanumanthaswamy BC, Shashidhara KC. Conversion of Areca leaf sheath into eco-friendly plates: A case study of remunerative micro enterprise. Inter. J. Trade \& Global Bus. Pers. 2014;1(3):2319-9059.

3. Omidbeygi M, Barzegar M, Hamidi Z, Naghdibadi $\mathrm{H}$. Antifungal activity of thyme, summer savory and clove essential oils against Aspergillus flavus in liquid medium and tomato paste, Food Control. 2007;18: 
1518-1523. doi: 10.1016/j.foodcont.2006.12.003

4. Schaad NW. Laboratory guide for the identification of plant pathogenic bacteria, $2^{\text {nd }}$ Ed. American Phytopathol. Soc. 1992:138pp.

5. Janaki S, Thenmozhi S, Mythili KK, Janani R. Bactericidal effect of various sterilizing sources on bacteria isolated from contaminated areca leaf plates in Tamil Nadu, J. Biol. Chem. Res. 2018;35(1):103-108.

6. Matan N, Warasri S, Nirundorn Matan. Antifungal activities of essential oils applied by dip-treatment on areca palm leaf sheath and persistence of their potency upon storage. Inter. Biodeterioration and Biodegradation. 2011;65:212-216. doi: 10.1016/j. ibiod.2010.09.009

7. Nitimongkonchi N. Utilization of cinnamon oil as antifungi in durian Paste, M.Sc. Thesis, Graduate School, Kasetsart University, Thailand 1999.

8. Lyratzopoulos G, Ellis M, Nerringer R. Invasive infection due to Penicillium species other than P. Marneffei. J. Infect. 2002;45(3)184-195. doi: 10.1053/ jinf.2002.1056
9. Dolatabadi S, Walther G, Ende AHGG, GS De Hoog. Diversity and delimitation of Rhizopus microsporus. Fung. Divers. 2014;64: 145-163. doi: 10.1007/s13225013-0229-6

10. Visagie CM, Houbraken J, Frisvad J.C, et al. Identification and nomenclature of the genus Penicillium. Stud. Mycol. 2014;78: 343-371. doi: 10.1016/j.simyco.2014.09.001

11. Gams W, Christensen M, Onions AH. Infrageneric taxa of Aspergillus. In advances in Penicillium and Aspergillus systematics. Samson RA, Pitt JI, eds. New York: Plenum Press: 1985:55-62. doi: 10.1007/978-14757-1856-0_5

12. HedayatiMT, Pasqualotto AC, Warn PA, BowyerP, Denning DW. Aspergillus flavus: human pathogen, allergen and mycotoxin producer. Microbiol. 2007;153:1677-1692. doi: 10.1099/mic.0.2007/007641-0

13. Sandoval-DenisM,SuttonDA, Cano-LiraJF, etal.Phylogeny of the clinically relevant species of the emerging fungus Trichoderma and their antifungal susceptibilities. J. Clin. Microbiol. 2014;52:2112-2125. 